\title{
Бухгалтерський облік
}

УДК 657.6

JEL Code $M 40, M 42$

Л.В. ГУЦАЛЕНКО*

(Національний університет біоресурсів і природокористування України, м. Київ, Украӥна)

\section{Контроль в системі управління}

У системі управління підприємством і його підрозділами важливу роль відіграє контроль. У широкому розумінні контроль - це перевірка відповідності фактичних характеристик (прочесів, діяльності, об'єктів) установленим вимогам (обмеженням). Метою статті є вивчення підходів до розуміння сутності системи та визначення місия та ролі контролю в системі управління. Досліджено сутність поняття «система» шляхом аналізу даного твердження у словникових і енциклопедичних статях та наукових дослідженнях. Як свідчить проведений аналіз, семантика загального визначення поняття «система» пов'язана з термінами «елемент», «частина», «об'єкт», «предмет». Доведено, щзо в наукових дослідженнях систему управління розглядають як елемент, шзо виокремлює закономірно взаємопов'язані явищз. Окреслено системний підхід щзоо економічних процесів в управлінні підприємством. Визначено, щзо система складається з частин, кожна з яких має свої власні цілі. Обтрунтовано, щуо система може розвиватись як під дією зовнішнього середовища, так $i$ під дією внутрішнього середовища. Доведено вплив інформаџійних потоків зовнішнього та внутрішнього середовища на адміністративні рішення, щзо підтверджує необхідність посилення дієвості та ролі контролю в системі управління підприємством з метою забезпечення його конкурентоспроможності на перспективу. Сформовано та схематично представлено місие контролю в системі управління. Виокремлено суб'єкти внутрішньогосподарського контролю на підприємствах класифікованих для потреб обліку та аудиту. Доведено, щзо контроль є не тільки функиією системи управління, а й дієвим інструментом для забезпечення належної організаџї роботи та оцінки будь-якого процесу чи виду діяльності, щзо дає змогу оперативно реагувати на негативні явища та здійснювати прогнозування діяльності на певний період як окремих складових, так підприємства в иілому.

Ключові слова: система, контроль, управління, функція управління, внутрішньогосподарський контроль. DOI: https://doi.org/10.33146/2307-9878-2019-1(83)-5-10

L.V. GUTSALENKO

(National University of Life and Environmental Sciences of Ukraine, Kyiv, Ukraine)

\section{Control in the Management System}

In the management system of the enterprise and its divisions, control plays an important role. In a broad sense, control is the verification of compliance of actual characteristics (processes, activities, objects) with the established requirements (restriction). The purpose of the article is to study the approaches to understanding the essence of the system and to determine the place and role of control in the management system. The essence of the concept of "system" was investigated by analyzing this statement in vocabulary and encyclopedic articles and scientific researches. As the analysis shows, the semantics of the general definition of the term "system" is connected with the terms "element", "part", "object", "object". It was proved that in scientific researches the management system is considered as an element that highlights naturally interrelated phenomena. The systematic approach to economic processes in enterprise management was defined. It was determined that the system consists of parts, each of which has its own goals. It was substantiated that the system can develop both under the influence of the external environment and under the influence of the internal environment. The influence of information flows of the external and internal environment on administrative decisions was proved. It confirms the need to enhance the effectiveness and role of control in the enterprise management system in order to ensure its competitiveness for the future. The place of control in the management system was formed and schematically presented. Subjects of internal control at different enterprises were identified for accounting purposes. It was proved that control is not only a function of the management system, but also an effective tool for ensuring proper organization of work and evaluation of any process or activity, which allows you to quickly respond to negative phenomena and forecast activity for a certain period of both individual components and the enterprise as a whole.

Keywords: system, control, management, functions of control, internal control.

\footnotetext{
Гуцаленко Любов Василівна, професор кафедри обліку та оподаткування Національного університету біоресурсів і природокористування України (м. Київ), доктор економічних наук, професор.
} 
Постановка проблеми. Суспільство вимагає об'єктивної інформації про всі процеси, які відбуваються у виробництві, а це означає, що виникає потреба у створенні такої системи як зовнішнього так i внутрішнього контролю, яка б охоплювала всі аспекти діяльності підприємства i задовольняла потребу керівництва в об' єктивному та оперативному отриманні інформації як облікового, так i технологічного характеру.

Контроль є невід’ємною функцією управління, ефективність та дієвість якої сприяє створенню умов для отримання оперативної та достовірної інформації про господарські операції та процеси, мінімізує виникнення ризиків та кризових ситуацій, що можуть негативно впливати на стратегічний розвиток суб'єктів господарювання.

Аналіз останніх досліджень і публікацій. Вагомий внесок в дослідження ролі контролю як функції управління зробили зарубіжні вчені. Зокрема класики науки управління Ф. Тейлор, Г. Емерсон, А. Файоль, Т. Форд, Д. Хан $\left[\begin{array}{llll}19, & 21, & 22, & 24\end{array}\right]$ стверджували, що без контролю неможливо управляти будь-яким процесом. Вчені сучасності І.К. Дрозд [3], С.В. Калюга [5], В.М. Максимова [11], М.С. Пушкар [13, 14], Н.В. Шевченко [26], В.О. Шевчук [27] зазначають, що ефективний контроль в системі управління націлений на оперативне прийняття управлінських рішень. Однак в умовах кризових явищ та стрімкого мінливого середовища ринкової економіки існують певні особливості, що впливають на конкурентоспроможність підприємств та визначають потребу постійного спостереження (за допомогою контрольних заходів) за елементами системи управління 3 метою підсилення іiі дієвості та впливу на забезпечення оперативності, законності та ефективності прийняття управлінських рішень. Саме на вирішення даної проблеми націлене дане дослідження.

Метою статті $\epsilon$ вивчення підходів до розуміння сутності системи та визначення місця та ролі контролю в системі управління.

Виклад основних результатів дослідження. Сьогодні контроль розглядається з різних точок зору, зокрема: як функція управління, як метод пізнання економічних явищ, як наука. Багатоаспектність даного поняття обумовлена тим, що теоретичне обгрунтування економічного змісту контролю грунтується на теорії пізнання та діалектиці.

Формування та реалізація функцій менеджменту зосереджена на системі управління конкретного суб' єкта господарювання. Для забезпечення ефективного управління необхідно оцінити діючий стан системи управління [17, с. 136] та визначити шляхи підвищення його якості.

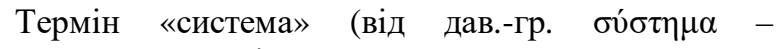
«сполучення», «ціле», «з'єднання») - множина взаємопов'язаних елементів, що утворюють єдине ціле, взаємодіють із середовищем та між собою, і мають мету. В наукових дослідженнях систему управління розглядають як елемент, що виокремлює закономірно взаємопов' язані явища.

В.Н. Садовський стверджував, що останнім часом системні ідеї проникли в науку й викликали відповідну позитивну реакцію практично в усьому спектрі сучасних наукових дисциплін. Як сказав свого часу Л .Берталанфі - «Системи повсюду» [11, с. 4].

На наше переконання, дослідження дієвості контролю як функції управління необхідно здійснювати 3 використанням системного підходу, який $\epsilon$ науковою основою для раціонального дослідження i ефективного управління різними системами, сукупністю методологічних принципів та положень, які дозволяють розглядати систему як єдине ціле 3 узгодженням діяльності всіх іiі підсистем. Системний підхід щодо економічних процесів - це визнання того, що будь-яка організація є системою, яка складається з частин, кожна 3 яких має свої власні цілі. Тому досягнути загальних цілей організації можна лише в тому випадку, якщо розглядати іï як єдину систему, прагнучи для цього зрозуміти та оцінити взаємодію всіх іiі частин і об’єднати їх на необхідній основі [12].

Наведемо результати теоретичних досліджень зарубіжних та вітчизняних вчених щодо тлумачення сутності «система» (табл. 1).

Аналіз різних тлумачень свідчить, що семантика загального визначення поняття «система» пов' язана 3 термінами «елемент», «частина», «об'єкт», «предмет», які підлягає дослідженню та вивченню. Зокрема І.К. Дрозд вважає, що складовими системи є елементи (об'єкти, частини, компоненти системи, кількість яких обмежена), властивості (якості елементів, які виражені в певних величинах і дають можливість кількісного вираження системи), зв'язки (те, що поєднує елементи та властивості системи в єдине ціле), структура системи (відображує найбільш суттєві і стійкі зв'язки між елементами системи та їх групами, які забезпечують основні властивості системи) [3, с. 11]. На думку О.В. Кустовської, можна виокремити такі головні групи властивих системам властивостей, які характеризують сутність і складність систем, зв'язок систем із зовнішнім середовищем, цілеспрямованість систем, параметри розвитку та функціонування систем [10, с. 19-20]. О.М. Петрук у визначенні системи виділя два аспекти: дескриптивний (описовий), що відповідає на питання про те, як відрізнити системний об'єкт від несистемного, та конструктивний, який дозволяє побудувати систему шляхом виділення іiї з середовища [12].

Сутність системної парадигми, що має концептуальну основу досліджував Я. Корнаі [7]. Об'єктом дослідження виступала цілісність, що постійно взаємодіє з зовнішніми факторами. Переваги, які характерні складовим елементам системи, притаманні i самій системі. Зі зміною системи змінюються переваги. Система може розвиватись як під дією зовнішнього середовища так $\mathrm{i}$ під дією адміністративних рішень. 
Підходи до тлумачення сутності «система»

\begin{tabular}{|c|c|c|c|c|c|c|c|c|c|}
\hline 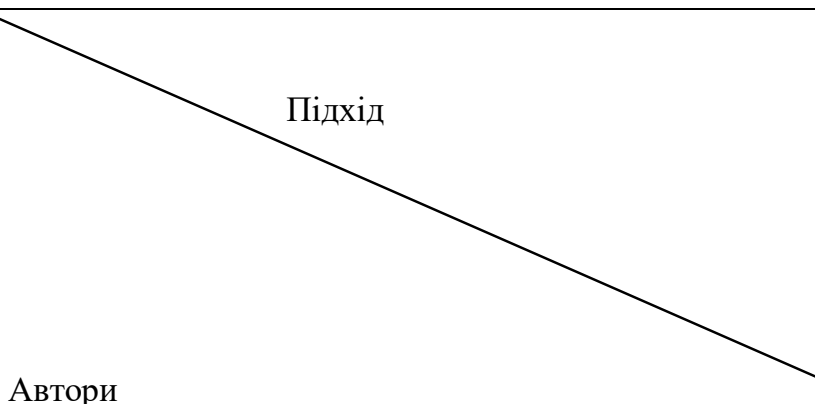 & 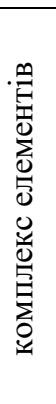 & 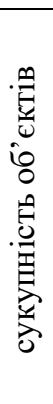 & 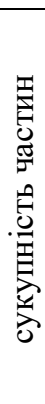 & 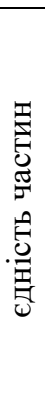 & 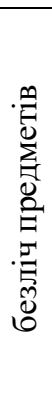 & 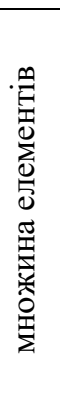 & 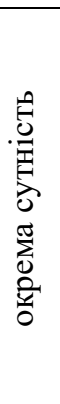 & 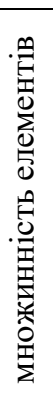 & \\
\hline Мочерний С. В. та ін. [4] & + & & & & & & & & \\
\hline Дрозд І.К. [3] & & & & & & + & & & \\
\hline Дем’яненко М.Я., Лузан Ю.Я., Саблук П.Т. та ін. [23] & & & + & & & & & & \\
\hline Садовський В.Н. [15] & & & & & + & & & & \\
\hline Садовський В.Н. [16] & & & & & & & + & & \\
\hline Пушкар М. С. [13] & & + & & & & & & & \\
\hline Колісник Г.М. [6] & & & & & & & & + & \\
\hline Тлумачний словник Ушакова [25] & & & & + & & & & & \\
\hline Тлумачний словник Ожегова [20] & & & & + & & & & & \\
\hline Економічна енциклопедія [28] & & & & & & & & + & \\
\hline Думка автора & & & & & & & & & + \\
\hline Кількість спільних ознак & 1 & 1 & 1 & 2 & 1 & & 1 & 1 & 1 \\
\hline
\end{tabular}

Джерело: узагальнено автором.

Для досягнення ефективного господарювання, в системі управління контроль $є$ однією із важливих функцій, оскільки через нього відбувається поєднання обліку, аналізу, прогнозування, регулювання діяльності підприємств. 3 однієї сторони контроль можна розглядати, як функцію управління, 3 другої - як підсистему обліку [2, с. 6062]. Оскільки контроль $є$ однією із функцій управління, то він не може існувати відокремлено від системи управління господарюючого суб'єкта в цілому та його організаційно-структурних складових.

Визначаючи місце підсистеми контролю у системі управління, необхідно враховувати, що контроль (як і планування, організування, мотивування та регулювання) $€$ однією 3 основних функцій менеджменту, реалізація якої дає змогу керівництву підприємства оцінювати, наскільки правильними $є$ його управлінські рішення, а також визначати потребу в здійсненні певних коректив у процесі реалізації цих рішень [9, с. 137].

М.М. Коцупатрий та У.О. Марчук стверджують, що більшість авторів (22\%) вважають контроль процесом та перевіркою, $19 \%$ - визначають сутність контролю як спостереження та систему, і лише $7 \%$ використовують заходи попередження та дії при визначенні його сутності [8, с. 14].

На думку М.С. Пушкаря, система контролю як функція управління має забезпечувати оцінку якості роботи підприємства. Управління за своєю сутністю є видом людської діяльності, спрямованої на вирішення проблем реалізації адекватної поведінки підприємства складному оточуючому середовищу, тому в циклі управління надзвичайно важливу роль відіграють інформаційні ресурси. Управління можна розглядати з точки зору інформаційного процесу, в якому оцінка рівня досягнення мети підприємства грунтується на відстеженні економічних явищ i процесів, виявленні тенденцій i відхилень як в діяльності підприємства, так і в його оточенні [13, c. 55-56].

Оцінюючи наукові підходи можна дійти висновку, що 3 розвитком ринкових відносин відбулося розмежування облікових та контрольних функцій та виокремлення місця i вагомої ролі контролю в системі управління господарюючих суб' єктів.

Дієвість функції контролю необхідно простежувати на всіх стадіях руху капіталу та охоплювати нею всі сторони економічного відтворення на мікро- та макрорівнях. Її дієвість має забезпечуватись суб'єктами контролю на всіх рівнях управління від менеджерів середньої ланки господарюючих суб'єктів до менеджерів владних державних структур. Результативність рішень менеджерів всіх рівнів залежить від якості отриманої ними інформації, тобто від рівня їх інформаційної обізнаності.

В зарубіжній практиці в системі управління особливо актуальним $\epsilon$ інтегрований внутрішній контроль (COSO-ERM) за допомогою якого можливо вчасно та об'єктивно оцінити ризики та загрози i сформувати умови результативного управління ситуацією. Інтегрована модель внутрішнього контролю містить вісім компонентів, які пов'язані між собою: внутрішне середовище здійснення контролю, формування цілей, опис процесів, ідентифікація та оцінка ризиків, спроби реагувати на ризики та управління ними, механізм контролю (контрольні заходи), організація інформаційного та комунікаційного обміну, здійснення моніторингу 
системи внутрішнього контролю та відстежування результатів реалізації контрольних заходів. На жаль в практичній діяльності вітчизняних підприємств управлінський персонал недооцінює роль внутрішнього (внутрішньогосподарського) контролю та іноді не приділяє йому належної уваги.

Вважаємо, що в умовах нестабільності ринкового середовища та кризових явищ особливе місце необхідно відвести об’єктивності інформації, яку отримують суб' єкти господарювання із внутрішнього та особливо зовнішнього середовища в якому вони функціонують. Тому контролю необхідно посилити свою дієвість та роль в системі управління підприємством 3 метою забезпечення його конкурентоспроможності на перспективу (рис. 1).

зовнішне середовище

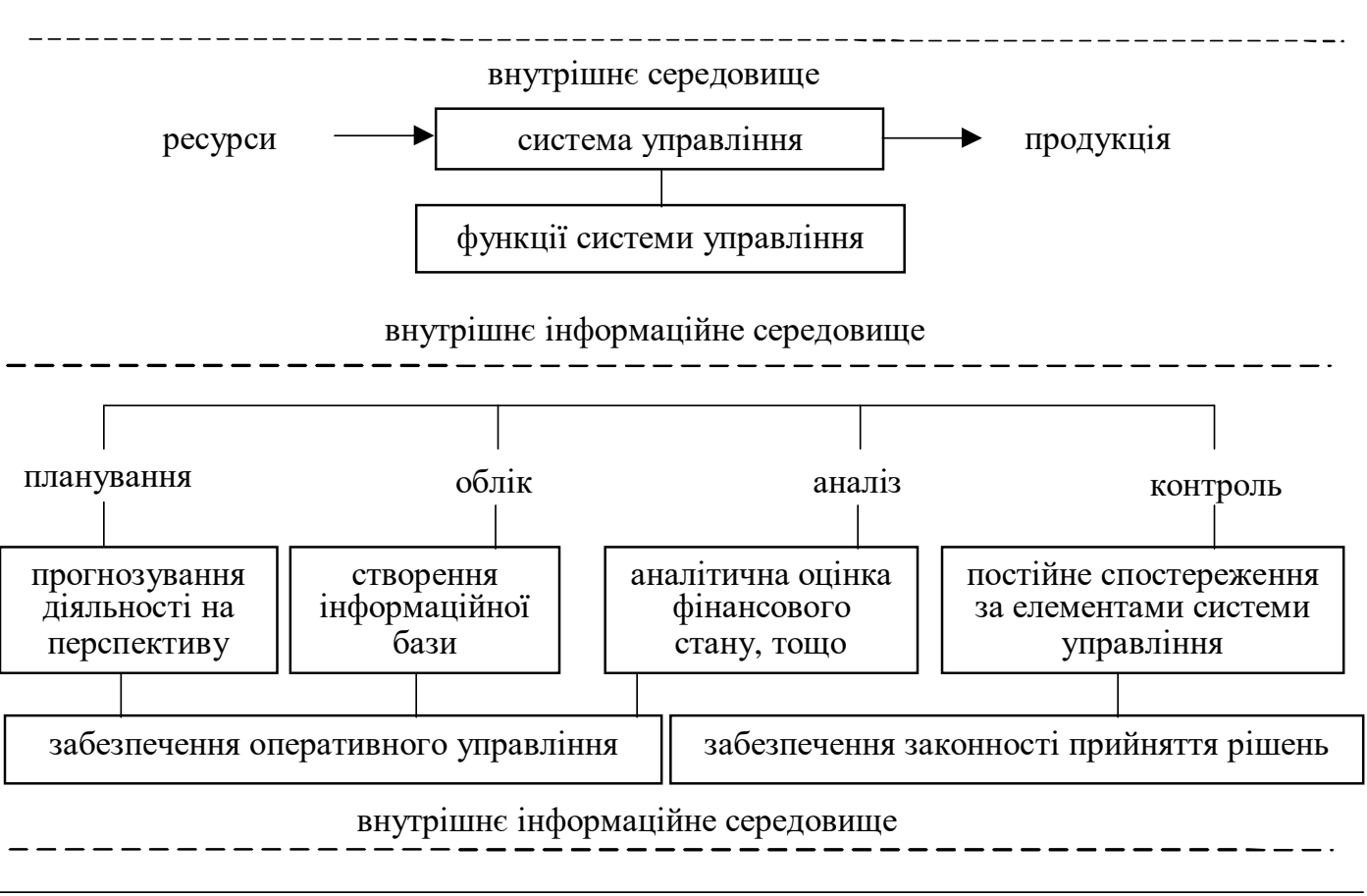

зовнішнє інформаційне середовище

Puc. 1. Місце контролю в системі управління

Джерело: сформовано автором.

У підсистемі контролю за фінансовогосподарською діяльністю підприємств та за реалізацією управлінських рішень основна роль має відводитись внутрішньогосподарському контролю. Індійський філософ Махатма Ганді дуже справедливо стверджував: «Контроль приносить користь лише тоді, коли він виходить зсередини» [18]. Внутрішньогосподарський контроль, як функція управління, $\epsilon$ засобом зворотного зв'язку між об'єктом управління та органом управління, інформуючи про дійсний стан об'єкта і фактичне виконання управлінських рішень [1].

Відповідно до ч. 2 ст. 2 Закону України «Про бухгалтерський облік та фінансову звітність в Україні», підприємства (крім бюджетних установ) можуть належати до мікропідприємств, малих, середніх або великих підприємств. Ідентифікуємо суб'єктів внутрішньогосподарського контролю для підприємств, що класифіковані для потреб обліку та аудиту відповідно до діючого законодавства України (табл. 2).

Зазначимо, що визначення суб' єктів внутрішньогосподарського контролю має пряму залежність від розмірів господарюючого суб' єкта та особливостей його діяльності [8, с. 40]. Регламентацію суб'єктів внутрішньогосподарського контролю, що діють в підприємствах України, доцільно здійснювати на підставі внутрішніх організаційно-управлінських актів.

Основним критерієм дієвості контролю, як функції управління, $€$ скасування формального підходу до його здійснення та адаптивність до швидких змін ринкового середовища на мікро- та макрорівнях.

Як свідчать наші дослідження, в діяльності господарюючих суб' єктів роль контролю недооцінена та залишається поза увагою можливість його впливу на процеси, що відбуваються у внутрішньому та зовнішньому середовищі підприємства.

Дієвість контролю 3 урахуванням зовнішнього середовища надасть можливість забезпечувати системне управління суб'єкта господарювання націлене на прогнозування його перспективного розвитку, а також впливати на формування фінансових результатів діяльності, що в свою чергу дозволить підприємству мати стійкі позиції та бути конкурентоспроможним. 
Суб'єкти внутрішньогосподарського контролю на підприємствах класифікованих для потреб обліку та аудиту

\begin{tabular}{|c|c|c|c|c|c|c|c|c|}
\hline \multirow[b]{2}{*}{ Класифікація підприємств } & \multicolumn{8}{|c|}{ Суб’єкти внутрішньогосподарського контролю } \\
\hline & 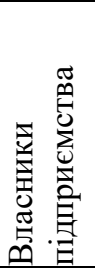 & 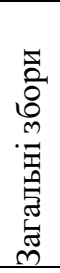 & 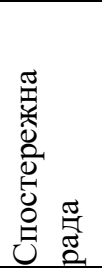 & 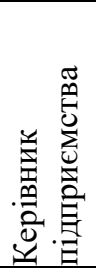 & 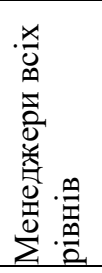 & 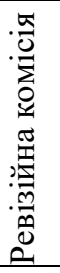 & 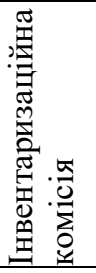 & 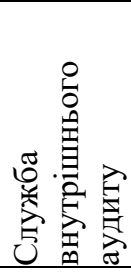 \\
\hline Мікропідприємства & + & & & + & & & & \\
\hline Малі підприємства & + & & & + & & & & \\
\hline Середні підприємства & + & + & & + & + & + & + & \\
\hline Великі підприємства & + & + & + & + & + & + & + & + \\
\hline
\end{tabular}

Джерело: сформовано автором.

Контроль в інтеграції з функціями планування, обліку та аналізу створює інформаційні можливості для життєдіяльності управлінського циклу [11, с. 4].

Погоджуємось 3 думкою В.О. Шевчука, що дослідження управлінської сутності контролю дають змогу абстрагувати його від інших функцій менеджменту і розглядати автономно, як систему, яка $\epsilon$ множиною елементів, що перебувають у відношеннях та зв'язках один 3 одним, утворюючи певну цілісність [27, с. 13-14].

Висновки. Таким чином, система управління має свої властивості та елементи. Постійне спостереження за елементами системи управління встановлюється функцією контролю, яка виступає гарантом забезпечення законності прийняття рішень. Дієвість функції контролю необхідно простежувати на всіх стадіях руху капіталу та охоплювати нею всі сторони економічного відтворення на мікро- та макрорівнях. Вчасно та об' єктивно оцінити ризики та загрози i сформувати умови результативного управління ситуацією можливо за допомогою інтегрованого внутрішнього контролю (COSO-ERM). Контроль $є$ не тільки функцією системи управління, але й дієвим інструментом для забезпечення належної організації роботи та оцінки будь-якого процесу чи виду діяльності, що дає змогу оперативно реагувати на негативні явища та здійснювати прогнозування діяльності на певний період як окремих складових, так підприємства в цілому.

\section{4 Список використаних джерел}

1. Галич О. А. Внутрішньогосподарський контроль в системі управління аграрних підприємств. Наукові праці Полтавської державної аграрної академї. 2012. Вип. 1(4). Т. 3. С. 26-30.

2. Гуцаленко Л. В. Адаптивна система обліку i контролю результатів діяльності сільськогосподарських підприємств: монографія. К.: ННЦ ІАЕ, 2010. 372 с.

3. Дрозд І. К. Контроль економічних систем: монографія. К.: Імекс-ЛТД, 2004. 312 с.

4. Економічна енциклопедія: у 3 т. / редкол.: відп. ред. С. В. Мочерний та ін. К.: Академія, 2000. 864 с.

5. Калюга Є. В. Фінансово-господарський контроль у системі управління: монографія. К.: Ельга, НікаЦентр, 2002. 360 с.
6. Колісник Г. М. Економічна сутність витрат i управління ними. Науковий вісник НЛТУ Украӥни. 2012. Вип. 19.8. С. 252-258.

7. Корнаи Я. Системная парадигма. Bonpocbl экономики. 2002. № 4. С. 4-22

8. Коцупатрий М. М., Марчук У. О. Внутрішньогосподарський контроль в управлінні діяльністю сільськогосподарських підприємств: монографія. Вінниця: ПП «ТД «Едельвейс і К», 2014. 268 с.

9. Кузьмін О. С., Мельник О. Г., Петришин Н. Я. Прикладний менеджмент. Львів: Видавництво Нац. унту «Львівська політехніка», 2009. 292 с.

10. Кустовська О. В. Методологія системного підходу та наукових досліджень: курс лекцій. Тернопіль: Економічна думка, 2005. 124 с.

11. Максімова В. Ф. Внутрішній контроль економічної діяльності промислового підприємства - системний підхід до розвитку. Одеса: ОДЕУ, 2005. 269 с.

12. Петрук О. М., Виговська Н. Г. Обгрунтування синергетичного підходу у дослідженні фінансового контролю. Облік і фінанси АПК. 2010. № 4. С. 110-114.

13. Пушкар М. С. Тенденції та закономірності розвитку бухгалтерського обліку в Україні (теоретикометодологічні аспекти): монографія. Тернопіль: Економічна думка, 1999. 424 с.

14. Пушкар М. С. Філософія обліку. Тернопіль: Картбланш, 2002. $157 \mathrm{c}$.

15. Садовский В. Н. Исследования по общей теории систем: сб. переводов / общ. ред. Садовского В.Н., Юдина Э. Г. М.: Прогресс, 1969. 520 с.

$\begin{array}{lll}\text { 16. Садовский } & \text { В. Н. Основания общей теории }\end{array}$ систем: логико- методологический анализ. М.: Наука, 1974. 279 c.

17. Сіменко I. Базові концептуальні положення управлінського аналізу у забезпечення ефективності функціонування підприємства. Вісник ТНЕУ. 2011. № 4. C. $135-145$.

18. Східна мудрість. Великі ідеї Махатми Ганді. URL: http://www.chervonograd.com.ua/gandi.php.

19. Тейлор Ф. У. Принцыпы научного менеджмента. URL: http://www.improvement.ru/bibliot/taylor/index.shtm

20. Толковый словарь Ожегова. URL: http://www.ozhegov-shvedova.ru/19-741515/СИСТЕМА

21. Файоль А., Эмерсон Г., Тейлор Ф., Форд Т. Управление - это наука и исскуство. М.: Республика, $1992.83 \mathrm{c}$. 
22. Файоль А. Общее и промышленное управление. М.: Контролинг, 1992. 344 с.

23. Фінансовий словник-довідник / M. Я. Дем'яненко, Ю. Я. Лузан, П. Т. Саблук та ін.; за ред. М. Я. Дем'яненка. К.: IAE УААН, 2003. 555 с.

24. Хан Д. П. Планирование и контроль, концепция контролинга. Москва: Финансы и статистика, 1997. $799 \mathrm{c}$.

25. Что такое система? Значение и толкование слова sistema, определение термина / Толковый словарь Ушакова. URL: http://www.onlinedics.ru/ slovar/ushakov/s/sistema.html

26. Шевченко Н. В. Критерії та показники оцінки ефективності державного фінансового контролю. Облік $i$ фінанси АПК. 2011. № 2. С. 82-85.

27. Шевчук В. О. Контроль господарських систем в суспільстві 3 перехідною економікою (проблеми теорії, організації, методології): монографія. К.: Київ. держ. торг.-екон. ун-т, 1998. $371 \mathrm{c.}$

28. Экономическая энциклопедия / Под редакцией Л. И. Абалкина. М.: ОАО «Издательство «Экономика», 1999. $1055 \mathrm{c}$.

\section{References}

1. Halych, O. A. (2012). Vnutrishnohospodarskyi kontrol $\mathrm{v}$ systemi upravlinnia ahrarnykh pidpryiemstv [Internal control in the management system of agricultural enterprises]. Naukovi pratsi Poltavskoi derzhavnoi ahrarnoi akademii, 1(4), Vol. 3, 26-30.

2. Hutsalenko, L. V. (2010). Adaptyvna systema obliku i kontroliu rezultativ diialnosti silskohospodarskykh pidpryiemstv [Adaptive accounting and control system of the agricultural enterprises' activity]. Kyiv: NNTs IAE.

3. Drozd, I. K. (2004). Kontrol ekonomichnykh system [Control of economic systems]. Kyiv: Imeks-LTD.

4. Mochernyi, S. V. (ed.) (2000). Ekonomichna entsyklopediia: u 3 t. [Economic Encyclopedia: in the 3 volums]. Kyiv: Akademiia.

5. Kaliuha, Ye. V. (2002). Finansovo-hospodarskyi kontrol u systemi upravlinnia [Financial control in the management system]. Kyiv: Elha, Nika-Tsentr.

6. Kolisnyk, H. M. (2012). Ekonomichna sutnist vytrat i upravlinnia nymy [The economic essence of costs and their management]. Naukovyi visnyk NLTU Ukrainy, (19.8), 252258.

7. Kornay, Ya. (2002). Systemnaia paradyhma [The system paradigm]. Voprosy ekonomiki, (4), 4-22

8. Kotsupatryi, M. M., Marchuk, U. O. (2014). Vnutrishnohospodarskyi kontrol $\mathrm{v}$ upravlinni diialnistiu silskohospodarskykh pidpryiemstv [Internal control in the management of agricultural enterprises]. Vinnytsia: PP «TD «Edelveis i K».

9. Kuzmin, O. Ye., Melnyk, O. H., Petryshyn, N. Ya. (2009). Prykladnyi menedzhment [Applied management]. Lviv: Vydavnytstvo Nats. un-tu «Lvivska politekhnika».

10. Kustovska, O. V. (2005). Metodolohiia systemnoho pidkhodu ta naukovykh doslidzhen [Methodology of systems approach and research]. Ternopil: Ekonomichna dumka.

11. Maksimova, V. F. (2005). Vnutrishnii kontrol ekonomichnoi diialnosti promyslovoho pidpryiemstva systemnyi pidkhid do rozvytku [Internal control of the economic activity of an industrial enterprise - a systematic approach to development]. Odesa: ODEU.
12. Petruk, O. M., Vyhovska, N. H. (2010). Obgruntuvannia synerhetychnoho pidkhodu u doslidzhenni finansovoho kontroliu [Rationale for a synergistic approach to the study of financial control]. Oblik $i$ finansy APK, (4), 110-114.

13. Pushkar, M. S. (1999). Tendentsii ta zakonomirnosti rozvytku bukhhalterskoho obliku v Ukraini (teoretykometodolohichni aspekty) [Trends and patterns of development of accounting in Ukraine (theoretical and methodological aspects)]. Ternopil: Ekonomichna dumka.

14. Pushkar, M. S. (2002). Filosofiia obliku [Accounting philosophy]. Ternopil: Kart-blansh.

15. Sadovskyi, V. N. (1969). Issledovaniya po obshchei teorii sistem [Research on the general theory of systems]. Moskva: Prohress.

16. Sadovskyi, V. N. (1974). Osnovaniya obshchei teorii sistem: lohiko-metodolohicheskii analiz [Foundations of the general theory of systems: logical methodological analysis]. Moskva: Nauka.

17. Simenko, I. (2011). Bazovi kontseptualni polozhennia upravlinskoho analizu u zabezpechennia efektyvnosti funktsionuvannia pidpryiemstva [Basic conceptual provisions of management analysis to ensure the efficiency of the enterprise]. Visnyk TNEU, (4), 135-145.

18. Skhidna mudrist. Velyki idei Makhatmy Gandi [Eastern wisdom. Big Ideas of Mahatma Gandhi]. Retrieved from http://www.chervonograd.com.ua/gandi.php.

19. Teilor, F. U. Printsypy nauchnoho menedzhmenta [Principles of scientific management]. Retrieved from: http://www.improvement.ru/bibliot/taylor/index.shtm

20. Tolkovyi slovar Ozhehova [Ozhegov Explanatory dictionary]. Retrieved from http://www.ozhegovshvedova.ru/19-741515/СИСТЕМА

21. Faiol, A., Emerson, H., Teilor, F., Ford, T. (1992). Upravlenie - eto nauka i isskustvo [Management is science and art]. Moskva: Respublika.

22. Faiol, A. (1992). Obshchee i promyshlennoe upravlenie [General and industrial management]. Moskva: Kontrolinh.

23. Demianenko, M. Ya., Luzan, Yu. Ya., Sabluk, P. T., Skupyi, V. M. et al. (2003). Finansovyi slovnyk-dovidnyk [Financial dictionary reference] (ed. by M. Ya. Demianenkj). Kyiv: IAE UAAN.

24. Khan, D. P. (1997). Planirovanie i kontrol, kontseptsiya kontrolinha [Planning and control, concept of controlling]. Moskva: Finansy i statistika.

25. Chto takoe sistema? Znachenie i tolkovanie slova sistema, opredelenie termina / Tolkovyi slovar Ushakova [What is a system? Meaning and interpretation of the word sistema, definition of the term / Ushakov Explanatory Dictionary]. Retrieved from http://www.onlinedics.ru/slovar/ ushakov/s/sistema.html

26. Shevchenko, N. V. (2011). Kryterii ta pokaznyky otsinky efektyvnosti derzhavnoho finansovoho kontroliu [Criteria and indicators for evaluating the effectiveness of state financial control]. Oblik i finansy APK, (2), 82-85.

27. Shevchuk, V. O. (1998). Kontrol hospodarskykh system $\mathrm{V}$ suspilstvi $\mathrm{z}$ perekhidnoiu ekonomikoiu (problemy teorii, orhanizatsii, metodolohii) [Control of economic systems in a society in transition (problems of theory, organization, methodology)]. Kyiv: Kyiv. derzh. torh.-ekon. un-t.

28. Abalkin, L. Y. (ed.) (1999). Ekonomicheskaia entsyklopediya [Economic Encyclopedia]. Moskva: $\mathrm{OAO} \ll$ Izdatelstvo «Ekonomika». 